\title{
14. A Room of Their Own
}

\author{
Young Women, Courtship, and the Night in Early Modern \\ England
}

\author{
Eleanor Hubbard
}

\begin{abstract}
In early modern England, poor young women were usually freer from patriarchal control and more independent in courtship than their more prosperous sisters. However, accounts of night-time merriment in church court records suggest that wealthy young women did sometimes enjoy their own semi-secret spaces for recreation and courtship. The late hours of the night could transform the enclosed, respectable space of the home into a space for youth culture when the house was large enough to accommodate several young people and a separate bedchamber for unmarried women. While nocturnal youth culture is often associated with young men carousing in public places, these incidents prompt us to consider how the meanings of domestic space changed after elders went to bed.
\end{abstract}

Keywords: night; youth; women; early modern; courtship; England; London

One morning in 1617, a maidservant was washing the parlour floor in the house of the wealthy Levant Company merchant Thomas Symonds when her master's daughter approached her with an exciting request. Joan Symonds 'entreated [Elizabeth Graves] to make her a posset at night when her father was gone to bed, and promised to get all things ready'. Hours later, when the house was dark and the doors locked against the outside world, Elizabeth made her way to Joan Symonds's room, where she found a fure burning merrily, and several young people. These were Joan herself, two menservants, Elizabeth's fellow maidservant Mary Mason, and Joan's sweetheart James Cartwright, who had been let into the house by one of the menservants, Edmund Markes. The servants made the posset, mixing hot milk with wine

Cohen, E.S. and M. Reeves (eds.), The Youth of Early Modern Women, Amsterdam University Press, 2018.

DOI: $10.5117 / 9789462984325 / \mathrm{CH} 14$ 
or ale so that it curdled, then spicing the heady mixture. The young people shared their treat, and 'were all merry at the eating thereof'. 'Elizabeth went to bed when the posset was eaten, weary from her work and mindful that she would be called to rise early the next morning to undertake the daily round of household chores. But the others stayed up until one or two in the morning, talking, laughing, and, in the case of Joan and James, kissing, while the merchant and his wife slept unawares in a different part of the house.

This posset party was no mere frivolous amusement for Joan Symonds, however much she might have enjoyed it. For young women in early modern England, courtship was of critical importance, offering them a limited but significant chance to determine the course of their future lives. ${ }^{2}$ For both men and women, and their respective families, personal and pragmatic considerations shaped the making of marriage, and parental approval was desirable if not always necessary. For many poor young women, who married relatively late and could expect little in the way of marriage portions from their parents, the path to a promising bridegroom was more likely to be impeded by poverty than by patriarchal control, at least on their side. The real challenge was finding a young man with good prospects who would take a penniless girl, and whose parents did not object. These young women often met and courted prospective husbands on their own, sometimes while working away from home as maidservants; their independence from familial control and support was very much a mixed blessing. In contrast, wealthier parents took a more active role in matchmaking, negotiating with one another and using the promise of substantial marriage portions to influence their children's choice.

While even the daughters of richer families expected to be able to reject undesirable suitors, it is generally thought that they were more likely to play a comparatively passive role in courtship, marrying young to candidates presented to them by their parents. However, the posset incident in St. Peter Cornhill and other similar escapades suggest that young women from wealthy families did sometimes have opportunities to create more or less secret spaces for youthful recreation and courtship. By meeting her suitor at night, abetted by other young people in the household, Joan Symonds demonstrated a striking ability to elude parental control by putting her material and social surroundings to good use. The late hours of the night

1 London Metropolitan Archives (LMA), Deposition of Elizabeth Graves, DL/C/225/139r. Spelling and punctuation have been modernized throughout the text.

2 On women's agency in courtship, see Adair, Courtship, 134-36; O'Hara, Courtship and Constraint; and Hubbard, City Women, 48-78. 
could transform the enclosed, respectable space of the home into a freer and more adventurous space, especially if the house were large enough to accommodate several young people and a separate bedchamber for unmarried women. While nocturnal youth culture is often associated with young men carousing in public places, these incidents prompt us to consider how the meanings of private, domestic spaces changed in the dark hours of the night, offering young women as well as men a reprieve from adult supervision and a chance to pursue illicit courtship.

Joan Symonds was a determined young woman, and this night meeting was not the only way in which she challenged convention. Indeed, a variety of witnesses, and even Joan herself, testified to her readiness to defy her father and stepmother in pursuit of her chosen match. However, the secret merriment in Joan's room illustrates both the opportunities young women in wealthy households had to carve out space and time for youthful recreation and courtship, and the dangers they faced in doing so. Inviting a young man into private female space put a young woman's reputation at risk even if the couple met in the company of other young people, and James Cartwright was well aware that he could gain leverage over his chosen bride by coming to her room at night. If Joan's daring enterprise in courtship strengthened her position relative to her father, it only undermined her ability to negotiate successfully with her suitor, leaving her disappointed and humiliated when their plans for marriage unravelled.

\section{Youth Culture, Time, and Space}

Before the later seventeenth century, ordinary people and the gentry alike generally shunned the night, rising early and going early to bed, locking their doors against the threat of the dark. ${ }^{3}$ Shops shut early and honest people stayed at home, leaving taverns and alehouses - if they remained open - to the dubious patronage of less respectable drinkers. Since people of good fame were not generally expected to be up and about at night, the dark hours remained the province of less reputable sorts, people whose poverty or youth excluded them from honourable responsibilities. Indeed, male youths were central denizens of the night. Male youth culture in England was not as elaborated as in some continental countries, but on occasion, some young (and sometimes older) men in early modern English cities and other places seized the night as their own. Rowdily roaming unlit streets, 
beating up the watch, getting drunk, and insulting honest folk, they used the cover of darkness to mock the patriarchal expectation that young bachelors should demean themselves modestly and discreetly toward their elders and betters. ${ }^{4}$ Sometimes they revelled in disorder, while at others they mimicked the disciplinary stance of men of authority, like the Cambridge scholars who found a woman hiding under a hedge, made her take off her clothes, and whipped her as a whore. 5

Sexual dominance was a potent ingredient in young men's night-time performances, and respectable young women were well advised to stay away from nocturnal wanderers, who were apt to assume that any woman out at night was fair game for harassment or rape. While wives and widows could walk the streets at night on their way to attend another woman's labour, there were no generally sanctioned occasions on which young, unmarried women could venture out, and both legitimate watchmen and groups of drunken men were likely to accost them. Young women who did walk abroad at night were regularly hauled into Bridewell as 'nightwalkers', liable to punishment even if they were not specifically accused of sexual offences. In theory, both men and women could be called 'nightwalkers', but in seventeenth-century London magistrates increasingly directed the accusation toward women, suggesting that their presence on night streets was particularly problematic, and objectionable in and of itself. ${ }^{6}$

Of course, young women who stayed up late could do so indoors, where the late hours of the evening provided some relief from the labours of the day. Once it was too dark to sew, with shops closed and the children asleep, even in modest households young people might sit up talking over neighbourhood happenings, eager to extend a brief moment of enjoyment. If their parents or employers were in bed, their talk could be especially free, and these conversations by the light of the kitchen fire sometimes took dangerous turns when servants felt free to dissect the behaviour of their elders. The 20-year-old apprentice John Pruddon reported in August 1639 that he, his younger fellow Richard Nicholson, and the maidservant Alice Stanley were all 'together at night in the kitchen' of their master, Philip Mote, when they began to discuss a man named Baker 'and a wench which was supposed to have been begotten with child by him'. The girl, a domestic servant, had lost her job because of the rumours, and, according to Pruddon, Alice Stanley criticized the girl's mistress for dismissing her, saying: 'Come, come, she 
had not need be against her [...] she had a child before she was married'.7 She spoke with too much freedom, for Pruddon deposed against her in a defamation case.

In rural areas, where long distances between houses might prevent young men and women from meeting during working hours, the night could be a valuable time for courtship. In communities where some amount of mutual sexual exploration was expected and customary, nocturnal courtship could be explicitly or tacitly condoned by a young woman's friends and family. In France, for example, young women gathered in private houses on long winter evenings to work and chat together in spinning bees that were frequently visited by young men. ${ }^{8}$ Such formalized nocturnal gatherings do not seem to have been common in England, but there too, country people sometimes courted at night. ${ }^{9}$ In the 1650 s, for example, the tailor Leonard Wheatcroft frequently visited his sweetheart in the evening, even spending whole nights with her in deep conversation and loving embraces. ${ }^{10}$ Her family's tolerance for these trysts was not particularly unusual. Even in the English Lowlands, where attitudes toward sex were generally stricter than in the Highlands, in the late sixteenth century, "[w] hen a marriage was looming, family and society alike were happy to condone a very marked relaxation of the usually tight norms governing sexual relations', according to Richard Adair. Unsurprisingly, a significant proportion of brides went pregnant to the altar. ${ }^{11}$

Even if young rural women's parents or employers disapproved of their suitors, they were more likely to find opportunities to escape supervision than their urban counterparts, snatching moments of illicit privacy behind hedges or in quiet gardens. Correspondingly, rates of illegitimacy and bridal pregnancy were lower in urban areas than in the country, and especially low in the busy London metropolis. ${ }^{12}$ The capital was a crowded place, with busy streets and houses often divided into lodgings, sometimes with the flimsiest of separations. ${ }^{13}$ Whether they sought romantic privacy or simply longed to breathe freely and enjoy themselves in youthful company, London girls struggled to escape watchful eyes and ears. Kitchen gossip might easily be overheard by a mistress in bed only steps away, for example, and many

8 Ekirch, At Day's Close, 195.

9 Koslofsky, Evening's Empire, 203-08.

10 Adair, Courtship, 170; and Parfitt and Houlbrooke, Courtship Narrative, 53.

11 Adair, Courtship, 170 and 100. 
housewives spent their days at work on the threshold, where they could see both the house and the street. ${ }^{14}$ The night offered no reprieve. Often, maidservants slept in a trundle bed in the same room as their master and mistress; at other times, beds were stuck wherever they fit, in kitchens, halls, and shops. ${ }^{15}$ The charm of walking out into green fields on Sundays was surely not due only to the pleasant surroundings.

How, then, did Joan Symonds conceal her night courtship from her parents, who were wholly opposed to her love for James Cartwright? In her case, living in a large household appears to have made the difference: her father's house was large enough to contain a room specifically allocated to Joan and her kinswoman Mary Mason, a room that could become the site of women's nocturnal youth culture. Even in substantial households, young women were unlikely to have private rooms, and might even share beds: Sir Martin Frobisher's stepdaughter slept in the same room as the waiting women and the chambermaids, for example. ${ }^{16}$ Shared rooms and beds may have made personal privacy and solitude elusive even in wealthy households, but they offered opportunities for late-night conversations that could be more intimate than daylight gossip. It was in bed, for example, that one Mary Fox asked her parents' maidservant, Elizabeth Page, whether she ever 'had to do with any man', and then confessed that she herself had twice had sex with a Mr. William Milward. ${ }^{17}$ The divisions of rank between servants and the daughters of their employers were blurred though not erased by the ubiquity of service as a life-cycle stage for unmarried women. Almost all female domestic servants were unmarried maidservants, and girls of almost any social rank might spend a portion of their youth serving in another household. ${ }^{18}$ Whether they were in service or not, sleeping together and sharing their own space fortified a sense of shared identity between young women.

Youthful bedfellows and the intimacy of the bedchamber play a prominent role in one of the few autobiographical texts by a young girl in the seventeenth century. In her memoir of the year 1603, Anne Clifford, the daughter and heiress of the Earl of Cumberland, recalled that as a thirteen-year-old girl she had formed her most intimate friendships with other young ladies with whom she shared a bed. In spring 1603 , she became close to two young 
kinswomen during the first night they spent together: 'I lay all night with my cousin Frances Bourchier and Mrs Mary Cary, which was the first beginning of the greatness between us. ${ }^{19}$ With frequent visits, the girls became 'more inward', and sometime later, when Anne's mother wished to punish her for riding ahead with a gentleman, she 'in her anger commanded that I should lie in a chamber alone, which I could not endure'. Fortunately, Anne escaped this dreadful fate when, that night, 'my cousin Frances got the key of my chamber and lay with me which was the first time I loved her so very well' (55). In her memoir, Anne did not disclose what she and Frances talked about or what they did, but for these young aristocratic women, the companionship of the bedchamber and the shared escape it offered from the careful surveillance of their formidable elders was clearly of deep emotional significance. Anne also recounted sleeping in the chamber of an older noblewoman as evidence of a valued relationship: before Queen Elizabeth's death, she wrote, 'I used to go much to the Court, and sometimes did I lie in my aunt of Warwick's chamber on a pallet, to whom I was much bound for her continual care and love of me' (43). However, the gracious favour the Countess of Warwick showed Anne by allowing her to sleep on a pallet in her room was quite different from the mutual intimacy that flourished between the teenage girls when they shared a room of their own.

Lena Cowen Orlin writes that shared beds and bedrooms 'allowed for a high level of mutual surveillance', which is why beds appeared relatively infrequently as sites of sexual transgressions. ${ }^{20}$ But even for courtship, companionship at night had its uses; young women might well wish to meet their suitors without their parents' knowledge or presence, but that did not necessarily mean they wanted to be entirely alone with them. The company of other young women made nocturnal courtship safer, rather than making it impossible. Youthful bonds between daughters of the house and maidservants and shared enjoyment of nocturnal merriment encouraged young people to keep one another's secrets from their elders. When Susan White met George Houghton late at night in 1615 , for example, she seems to have entertained him in company with a maidservant and her own sister, at least part of the time. She confessed that he 'was divers times let in to [her] mother's house in the evening when her mother was in bed, and the maid prepared victuals ready and gave as good entertainment to the said George as they could'. Sometimes Susan's sister stayed up also, but sometimes George stayed after she had gone to bed, and the couple 'did sometime sit 
up till twelve or one of the clock in the night'. ${ }^{21}$ Like Joan Symonds, Susan wished to marry her suitor, but her parents were opposed to the match.

Night courting also occurred in large aristocratic households, where young women in service had enough space and critical mass to pursue romantic adventures. Some of these might be humble domestic servants, but even young gentlewomen frequently entered service in noble houses, in hopes of gaining valuable connections, fashionable skills, and social polish. One of these was Elizabeth Willoughby, who served Lady Constance Lucy and Sir William Bowyer among others in the fashionable parishes of St. Anne Blackfriars and St. Margaret's Westminster. When she sued one John Goodyear for a matrimonial contract, most of her fellow maidservants supported her case, usually signing their depositions in elegant if unpractised italic hands. ${ }^{22}$ However, their credit was impugned by some other witnesses, mostly men, who drew attention to the young women's close friendships and eventful romantic lives. In particular, they reported that Elizabeth and her close friend Anne Johnson had entertained young men who climbed 'into the chamber through the window' at night when they were fellow servants in the house of the Dean of St. Paul, namely Anne's suitor James Johnson. ${ }^{23}$ The two gentlewomen were thought to have abetted one another's escapades: a man who had often visited Elizabeth at the time noted 'great love and familiarity between them'. ${ }^{24}$ While they were not accused specifically of sexual laxity, Elizabeth was reported to be a dashing young woman, who once boasted of having drunk 'seven pints of sack hand to hand to a waterman'. ${ }^{25}$ She and Anne had had numerous suitors: one rejected swain had supposedly tattooed Elizabeth's name on his chest before departing to Bermuda, while another had given her expensive gifts of jewellery, money, 'silk stockings, silk garters, Spanish leather shoes and roses on them,. ${ }^{26}$ Another rejected suitor, the tailor John Stonyer, reported telling Goodyear that Elizabeth 'was not a fit marriage for such tradesmen as [he] and the said John Goodyear were, for $[. .$.$] if she had, she had been married long before that time.. { }^{27}$ The

\footnotetext{
21 LMA, Personal answer of Susan White, DL/C/223/70v.

22 LMA, Depositions of Anne Johnson (DL/C/222/14), Anne Ranger (DL/C/222/75v), Margaret Usman (DL/C/222/132v-34r), and Mary Davies (DL/C/222/150-51).

23 LMA, Depositions of Thomas Blundell (DL/C/222/4or), and John Stonyer (DL/C/223/146v).

24 LMA, John Stonyer, DL/C/223/146r.

25 LMA, Thomas Blundell, DL/C/222/40r.

26 LMA, Depositions of Richard Waller (DL/C/222/38v-39r), Joyce Mowlso (DL/C/223/142v), and Thomas Blundell (DL/C/222/4or).

27 LMA, John Stonyer, DL/C/223/146v.
} 
gallantry that flourished in these great households was out of place in the sober world of London tradesmen.

Shared youth seems to have been an essential ingredient in nocturnal merriment. In Joan Symonds's case, young people of substantially different status shared in her posset party. Joan herself was the daughter of a wealthy merchant, and James Cartwright had high hopes of prosperity. In contrast, Mary Mason was a poor relation who worked for her keep, while Elizabeth Graves, a maidservant from Cambridgeshire in her mid-twenties, was humbler still: her labour involved scrubbing the floor and she slept in a different place from Joan's room, perhaps in a garret or the kitchen. The menservants probably occupied an intermediate position. The social hierarchy was not erased by the participants' shared youth: the humblest servant made the posset, and all those present surely deferred to the wishes of Joan and James. However, for all her fiery independence, as an unmarried daughter living at home, Joan was also a subordinate member of the household, and no social inhibitions seem to have prevented the master's daughter and the master's servants from enjoying the forbidden pleasure of a midnight treat together. All were subjected to the authority and moral surveillance of their elders during the day, and for them night festivities may have provided a welcome reprieve. If youth united the merry-makers, however, gender divided them, for young women were more vulnerable to scandal than young men, and secret courtship exposed them to potential harm.

\section{Compromising Courtship}

Shared youth and shared space combined to create the opportunity for nocturnal festivity, spiced with a hint of danger, for, aside from the risk of parental wrath, a young woman's reputation could indeed suffer if a suitor went too far or if stories reached the wrong ears. But if danger made night meetings especially delicious, it could also leave daring young women with a bitter aftertaste. As Joan Symonds's case makes clear, early modern English cultural narratives that cast young women as castles to be besieged or treasures to be won left them in a vulnerable position when they allowed their lovers into their homes late at night. By all accounts, Joan was deeply in love with James, and her depth of feeling left her at risk of exploitation on the part of her subtler suitor. The fact that their secret nocturnal meetings took place on her ground helped her mitigate the danger, but in the end she surely looked back on the night episodes with hurt and anger. If these cases show how determined young early modern gentlewomen could be in pursuit 
of a chosen bridegroom, they also reveal the constraints that hampered their ability to act, and the heavy price that could be exacted for their daring.

The specific circumstances of the legal suit that led Elizabeth Graves to depose about making a posset render her testimony particularly valuable. James Cartwright claimed that the two had entered a matrimonial contract by uttering the formulaic words that bound them together in God's sight. In such suits, some deponents often presented vivid, detailed depictions of courtship that were flatly denied by other witnesses, making it hard to untangle fact from fiction. However, Joan Symonds never denied that she had been in love with James Cartwright or engaged in courtship with him, that she had intended and hoped to marry him, or even that she had previously asserted they were contracted together. Instead, she repeatedly affirmed that her promise to marry James had been contingent on his proving that he had an estate of 2000 pounds, and obtaining her father's good will. Since he had fulfilled neither condition, and had showed through his behaviour that he had no intention of trying, she argued that she was completely free of any obligation to him. Crucially, she did not dispute spending time with James at night without her parents' knowledge.

Like many young Londoners, Joan Symonds grew to esteem a member of her own household, her father's apprentice. During the first years of his apprenticeship, as he prepared to journey to the Levant on his master's business, James Cartwright presumably learned as much as he could about the eastern Mediterranean trades, the intricacies of book-keeping, and useful languages. He also lived on close terms with his elderly master's young daughter; at a time in which business could be conducted at home as well as at the Exchange or the counting house, there must have been innumerable occasions for the young people to meet and talk together. They developed an understanding that persisted after he sailed for Istanbul to serve as a factor for his master, and to do as much business as he could.

Levant Company factors often found life abroad to be full of cares, for, in addition to figuring out how to negotiate the exotic, polyglot world of the Ottoman Empire, they had to develop their relationships with people in England. Unlike the East India Company, the Levant Company was not a joint stock company, but rather just an association of merchants who shared in a monopoly on English trade with the Ottoman Empire and Venice. For young factors, wealth was by no means certain, but depended on their ability to nurture ties with English investors who would trust them to trade on their account, rewarding them with a percentage of the goods. James Cartwright would trade for his master, but also on his own account and those of others, if he could convince them to trust him. Like others, 
he probably spent a great deal of time writing home, trying to establish his professional reputation as a competent and skilful merchant. ${ }^{28}$

In addition to writing feverishly to his relatives, friends, and commercial contacts, Cartwright seems to have kept in touch with Joan Symonds, writing to her in an assured, even boastful style of his success. Thomas Symonds later remembered that it might have been during James's absence that Joan first approached him to talk about her marriage. As he recalled, she told him 'that she could be well contented to have [James] for her husband', arguing that even though he was still only an apprentice, he was rich enough to marry a gentlewoman of her standing: 'James should show [him] that he had an estate of $£ 2000$ whereby he might be able to maintain her', she asserted.

To Joan's dismay, her claim had the opposite effect from that which she had intended. Rather than being impressed by James's alleged wealth, Symonds immediately became suspicious. James had had only had 300 pounds when he began his apprenticeship, and so Symonds believed that if he had indeed become so rich, he had done so through fraud. ${ }^{29} \mathrm{He}$ was especially concerned because, in fact, James's performance as a factor had been far from satisfactory. Recently, by his own account, the young man had lost a large sum of money 'by a Jew in Constantinople'. Faced with Joan's brave words, Thomas Symonds suspected that James had lied to him about the supposed loss, and had embezzled at least part of the sum..$^{30}$ Given the great distance between London and the Ottoman capital, it was difficult if not impossible for London-based merchants to verify the probity of their agents abroad, and, once raised, Thomas Symonds's doubts were not easily put to rest. James's alleged fortune proved to be a fatal stumbling block.

James Cartwright appears to have returned to London soon after this conversation, perhaps having been recalled by his angry master; ordinarily he would have spent several years abroad. When he returned from the Levant, Symonds called him into his counting house and asked him whether he loved his daughter; James denied it, and refused to provide Symonds with any proof of his estate. Unconvinced, Symonds took the precautionary step of putting a 'caveat into the court' to stop any marriage licence being issued for Joan, so that the couple would have to publically state their intention to marry well in advance before any church ceremony could be performed.$^{31}$

28 Games, Web of Empire, 90.

29 LMA, Deposition of Thomas Symonds, DL/C/225/127.

30 LMA, Personal answer of James Cartwright (DL/C/192/25v), and deposition of Humphrey Peate (DL/C/225/134r).

31 LMA, Thomas Symonds, DL/C/225/127v. 
Awkwardly, James Cartwright continued to live in the Symonds household, at least for a while, and he and Joan found many occasions to spend time together. Elizabeth Graves, the maidservant, deposed that 'they desired to be private and would for the most part be together alone without other company'. When James fell gravely ill, Thomas Symonds hired a nurse-keeper to look after him, but Joan also tended him devotedly, being 'very tender over him and desirous he should have anything that he wanted'. ${ }^{2}$ She even 'lay upon the bed and held his the said James Cartwright's head when he did cast and ease his stomach', according to her sister. The illness was severe: Joan recounted to a friend that 'she thought he was at the point of death, which sight struck her with such grief that if her sister had not come in and cut her lace she thought she should have died'.33 There was some talk about James being sent to Aleppo for years to serve as consul, perhaps because Symonds was so eager to remove him from his daughter's vicinity. Anne Edgeworth, another maidservant, heard her say that she would wait seven years for him if need be. ${ }^{34}$

James did not sail to Aleppo, but he did leave Symonds's service, and his house, ostensibly moving out because of a disagreement with his master's son. After that, the couple met at the house of Mary Norman, a painter's wife, where they remained 'together sometimes by the space of an hour and sometimes by the space of two hours kissing and dealing together in familiar manner showing great love and affection one to the other'. Mary Norman thought Joan was 'very desirous to be married [...] and to have it speedily effected'. Not all of their talk was happy, however: Joan was 'very importunate' with James 'to show his estate unto her father whereby they might have his good will', but he 'said he could not do it, and asked why that should be required of him more than it was of those that married his other daughters'. Joan, no fool, replied that that there were doubts about how he had gotten his money. 35

Joan was playing a dangerous and difficult game. To fulfil her desires, she had to convince James to reveal his estate, and hope that her father would forgive any irregularities in its provenance. She had more success, it seems, with her father than her lover, for James kept mum despite repeated efforts to get him to reveal his estate and behave like a respectful suitor.

32 LMA, Elizabeth Graves, DL/C/225/138.

33 LMA, Depositions of Mary Peate, married sister of Joan Symonds (DL/C/225/136r), and Mary Norman (DL/C/225/136r).

34 LMA, Deposition of Anne Edworth, DL/C/225/140r.

LMA, Mary Norman, DL/C/225136v-37r. 
Appreciating his formidable daughter's force of will, Symonds reportedly tried to tempt Joan with other marriage prospects, beginning with two linen drapers. Joan remained cold to the proposals, and even affirmed that she 'could not undo that she had done with the said James Cartwright and that she was contracted or made sure to him'. In fact she was not contracted, she later deposed, but rather said she was as a strategy 'to draw her father to like thereof [...] she used those speeches only to get her father's goodwill'. ${ }^{6}$

Having had no luck with the linen drapers, Symonds progressed to bribery, offering Joan an unusually large portion if she would marry a knight. He deposed that 'hearing that Sir John Suckling [...] was a suitor to one Mistress Hawkins a widow, and that she was worth 3000 pounds', he said merrily that 'a maid with 2000 pounds was as good as a widow with 3000 pounds [...] Joan, how likest thou of Sir John Suckling? I could be contented to give 2000 pounds with thee in marriage for such a preferment. If I bring him to thee shall he be welcome?'37 In her own deposition, Joan said her father offered her 3000 pounds, and threatened that if she 'would not give entertainment to [Suckling] he would presently turn her out of his doors', but she remained obdurate, stating that 'although he would give her three times as much to her portion yet her conscience would not suffer her to forsake the said James Cartwright'. ${ }^{8}$ The wealthy Levant Company merchant Benjamin Barron met with an equally positive refusal: 'they were all base fellows in respect of James Cartwright', she told her sister. ${ }^{39}$ Thomas Symonds seems to have tried to exercise some strict paternal authority by sending Joan into the country, where it was supposed that the purer air would help with her green sickness, but she would not go, threatening to run away with James 'if her father went about to force her to go'. ${ }^{40}$

Her strategy seems to have worked. Thomas Symonds deposed that he eventually offered James that he could marry Joan with a good portion and keep his ill-gotten gains if he would only 'deal plainly' with him, but to no avail. In conversations with Joan, James apparently claimed that he had wagered a large sum of money that he could marry her without disclosing his fortune - a story Symonds met with withering scepticism. ${ }^{41}$ James's stubborn silence confused and frustrated both Joan Symonds and her father. It is possible that throughout the negotiations, he was more

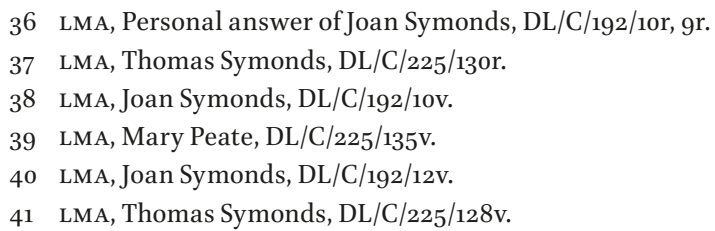


interested in using her love for him as a bargaining chip in his complicated financial dealings with Thomas Symonds than anything else. He may well have embezzled a large amount of money from his erstwhile master. If he were able to convince Joan to marry him without her father's consent, then presumably Thomas Symonds would be under considerable pressure to forgive him for his daughter's sake. Otherwise, he could hope to be bought off, forgiven his theft if he would only go away and leave Joan Symonds alone. He did, in fact, admit that he had said that if Thomas Symonds 'would refer a difference of accounts for monies of this respondent lost by a Jew in Constantinople to arbitrament, that then he [...] would be contented to give the said Joan a discharge'. ${ }^{42}$

It is in this precarious situation that James Cartwright visited Joan Symonds twice at night. The furst time, she expected his presence, and got things ready for a posset. The second time, he came as a surprise. Joan reported that one evening, when she had put her father to bed and went to her chamber to go to her own bed, she was astonished to find James Cartwright there. She told him 'it was no fit time to come to her at that time of the night, and prayed him to go out', but he protested that he would 'offer no unkindness unto her'. In any case, he could no longer leave the house: Edmund Markes, the manservant who had let him in, 'said that the keys were carried up into her father's chamber so as he could not then get out of the doors'. So, Joan deposed, James stayed all night in her room 'against [her] mind'. This time there was no party, but Markes stayed until 'about two or three of the clock in the morning', and he went away and Mary Mason, Joan's bedfellow, went to bed. Joan and James 'sat up and were in familiar talk and discourse all night', sitting on the bedside where Mary was sleeping, 'there being no other bed in the same chamber'. Joan first said that they were 'sometimes kissing each other', but the phrase was subsequently struck out. ${ }^{43}$ The next morning, in a turn worthy of the stage, James hid in a springlock closet, shut up securely until Thomas Symonds went to the Exchange, and Markes let him out.

James's intentions in this nocturnal visit do not seem to have been innocent. He continued to press his love to Joan in person, while refusing to speak with her father about his suit or his fortune. According to Joan's father, when she persisted in refusing to marry James without her father's consent, he suggested that she had no other choice, having compromised herself with him: 'if she would not be married to him [...] then he would 
publish her for a whore whereby she should be fit for no other man and that then he would go beyond the seas'. If he hoped to intimidate Joan, he miscalculated. Joan could forgive James's crooked dealings with her father, but this insult rankled. Afterward, Thomas Symonds claimed, Joan swore 'that if there were no more men in the world she would never be married to the said James Cartwright'. ${ }^{4}$

Despite her elaborate efforts to influence her father on the one hand and her lover on the other, Joan failed to obtain the marriage she wanted - no surprise given that the very same assertions that strengthened her hand with her father weakened her ability to bring her suitor to terms. However, James did not make good on his threat; in court at least, he shied away from asserting that they had committed fornication. Mary Mason did not depose in the case, but her presence in Joan's bedchamber allowed Thomas Symonds to assert indignantly that of course the couple had never been together alone at night. ${ }^{45}$ Young gentlewomen like Joan Symonds could create secret spaces for youthful courtship and recreation, away from the eyes and ears of their elders, but they were well advised to do so in the company of female companions. Caught between controlling parents and calculating suitors, they would need whatever allies they could muster.

Of course, not all young women who shared night spaces were emotionally intimate or supportive friends. Mary Mason, the poor relation, may have kept Joan's secret grudgingly; she may have been prevented from deposing because her evidence would have been harmful. However, the incidents described above are a useful reminder that in wealthy households, unmarried women's bedchambers were not just sites of sleep and labour. At night, they were also spaces where young women could speak without being overheard by their elders, exchange confidences, and even engage in secret courtship, both protected and constrained by one another's company. These moments of youth culture - if they deserve that name - may have been fleeting and hushed, but in a society that often consigned young women to silence and subordination, they were probably precious all the same. 


\section{Works Cited}

\section{Primary Sources}

London Metropolitan Archives, Diocese of London Consistory Court

Deposition Books:

DL/C/222, November 1613-February 1615

DL/C/223, January 1615-February 1615

DL/C/225, June 1617-April 1619

DL/C/235, November 1637-June 1640

Personal Answers Books:

DL/C/192, June 1617-February 1621

Clifford, Anne. The Memoir of 1603 and the Diary of $1616-1618$, edited by Katherine Acheson. Peterborough, on: Broadview, 2007.

\section{Secondary Sources}

Adair, Robert. Courtship, Illegitimacy and Marriage in Early Modern England. Manchester: Manchester University Press, 1996.

Beaumont, Matthew. Nightwalking: A Nocturnal History of London Chaucer to Dickens. London: Verso, 2015.

Crane, Mary Thomas. 'Illicit Privacy and Outdoor Spaces in Early Modern England'. Journal for Early Modern Cultural Studies 9, no. 1 (2009): 4-22.

Ekirch, A. Roger. At Day's Close: Night in Times Past. New York: Norton, 2005.

Flather, Amanda. Gender and Space in Early Modern England. Woodbridge, UK; Rochester, NY: Royal Historical Society/Boydell Press, 2007.

Games, Alison. The Web of Empire: English Cosmopolitans in an Age of Expansion 1560-166o. Oxford: Oxford University Press, 2008.

Gowing, Laura. Common Bodies: Women, Touch and Power in Seventeenth-Century England. New Haven: Yale University Press, 2003.

Griffiths, Paul. 'Meanings of Nightwalking in Early Modern England'. The Seventeenth Century 13, no. 2 (1998): 212-38.

-. Lost Londons: Change, Crime and Control in the Capital City 1550-1660. Cambridge: Cambridge University Press, 2008.

Hubbard, Eleanor. City Women: Money, Sex, and the Social Order in Early Modern London. Oxford: Oxford University Press, 2012.

Koslofsky, Craig. Evening's Empire: A History of the Night in Early Modern Europe. Cambridge: Cambridge University Press, 2011.

Kussmaul, Ann. Servants in Husbandry in Early Modern England. Cambridge:

Cambridge University Press, 1981. 
O'Hara, Diana. Courtship and Constraint: Rethinking the Making of Marriage in Tudor England. Manchester: Manchester University Press, 2000.

Orlin, Lena Cowen. Locating Privacy in Tudor London. Oxford: Oxford University Press, 2007.

Parfitt, George, and Ralph Houlbrooke, eds. The Courtship Narrative of Leonard Wheatcroft, Derbyshire Yeoman. Reading: Whiteknights, 1986.

Shepard, Alexandra. Meanings of Manhood in Early Modern England. Oxford: Oxford University Press, 2003.

\section{About the author}

Eleanor Hubbard is an Assistant Professor of History at Princeton University. She is a social and cultural historian of early modern Britain, and the author of City Women: Money, Sex, and the Social Order in Early Modern London (Oxford University Press, 2012) as well as articles on female literacy, The Taming of the Shrew, and early modern British sailors. She is currently working on a book manuscript tentatively entitled Englishmen at Sea: Sailors, Merchants, and Empire 1580-1620. Hubbard received her Ph.D. from Harvard University in 2009 . 
